\title{
Seed Funding Programs in a Comprehensive Liberal Arts and Sciences College
}

\author{
Carl W. Lejuez, Dean, College of Liberal Arts \& Sciences, University of \\ Kansas
}
Jessica Beeson, Director of Research and Engagement, College of Liberal Arts \& Sciences, University of Kansas
Maureen Cole, Assistant Director of Research and Engagement, College of Liberal Arts \& Sciences, University of Kansas

\begin{abstract}
eed funding is crucial to the success and growth of a college of liberal arts and sciences. The current paper outlines common and unique features of seed programs within and across Universities, reviews a case study from the college of behavioral and social sciences (BSOS) at the University of Maryland, and discusses key considerations in implementing a seed program within a college of liberal arts and sciences.
\end{abstract}

\section{Overview}

The current manuscript provides an overview of seed funding and discusses the rationale for such programs as well as the details in their construction and execution. The information included here is based on data and approaches pulled from available online resources, publications from groups such as the National Leadership Council, and a survey of college deans (see below for details). Additionally, we highlight results of the University of Maryland Dean's Research Initiative in the College of Behavioral and Social Sciences, which was directed by the first author in his previous role as associate dean for research.

To provide specifics on our survey to address how seed funding is undertaken at comparable institutions, we contacted 10 deans from geographical and missionsimilar universities with a single comprehensive college of liberal arts and sci- ences or arts and sciences. Questions focused on whether their college offered seed grant funding, size of awards offered, measurement of success, impact of the funding, and their reflections on these programs. Eight of the 10 deans that we contacted responded, and half of those indicated that their College offered seed grant funding. Of those that did not, the availability of funds through central university offices and seed funds not being viewed as a good use of limited budget were cited as the top reasons why they did not offer seed funds for research.

Common Features of a Seed Funding Program

\section{Goals and Benefits}

Seed funding programs provide a tool to support emerging, cross-campus research strengths that exist and fit into campus mission/goals. They can be targeted to and facilitate the impact of strategic goals of a college and the campus 
more broadly. Seed funding programs send an important message about research value and can be used to stimulate productivity (grants, intellectual products, student experience). These programs can be focused on proactive efforts but also can be crucial for providing a bridge for productive and previously funded researchers through lean times.

Our survey indicated the most common rationale for seed funding was for building interdisciplinary bridges, particularly when the work may not be ready for funding from federal agencies particularly in the case where the work is sufficiently new and may push the boundaries of those providing peer review. These interdisciplinary applications across units (often referred to as Collaboratories or Colaboratories) were also reported to provide a strong return on investment. Next most common was the funding of small and medium sized grants to a single investigator, as well as bridge funding. Most but not all programs provided priority to junior investigators. While most programs allowed funding to faculty to graduate students, few programs offered seed funding directly to graduate students for their research.

Not surprisingly, seed funding programs were reported in our survey to have an important impact on faculty morale. However, it was also noted that the competitive aspect that comes in the likely case where there isn't sufficient funding for all projects can also negatively impact morale in at least a small subset of faculty.

Notably, our survey indicated a greater focus on the sciences and less clarity in terms of the role of seed funding for the arts and humanities. Seed funding for disciplines in the arts and humanities have unique challenges and opportunities. Often faculty in these disciplines look to seed funding to support one-off intellectual projects such as completing a book or creating a piece of art that may not take the same step-wise format that many seed funded projects in the sciences take. While these projects may not generate larger external funding, they do contribute to the larger body of research and the status of the college. Arts and humanities faculty strengthen interdisciplinary, multi-unit projects involving faculty from the natural and social sciences. Examples of this can be found in large-scale research projects around themes such as migration, environmental sustainability and human trafficking, to name a few. Arts and humanities departments tend to have larger teaching loads than their counterparts in other disciplines, making funding teaching releases for faculty participating in the above research projects a particularly attractive option for the use of seed funds. To address the issue of equitable distribution of funds across disciplines, a few deans in our survey indicated offering separate allocations for different divisions to ensure sufficient support for the art and humanities.

\section{Use of funds}

Similar to the variability of the types of projects seed funding supports, there is considerable diversity in how funds are allocated to these projects In our survey and other research, we found that there does not seem to be a gold standard in regards to the budget criteria. Some programs focus funds on 
equipment and costs associated with gaining pilot data, including research related travel, while others focus on "opportunity costs" such as course release time or summer salary. The scale of the project as well as the discipline of the faculty member often dictate what items are included on the budget.

Our survey indicated travel, pilot data, and equipment costs as the most common allowable uses of funds followed by course releases and summer salary. There are also examples of seed funds where special criteria are laid out by the unit with the call for applications. For example, in some cases there is a clear requirement that projects must articulate direct benefits to students; requiring that the narrative and budget materials must clearly define the number of students who will be impacted by this project and how they will be impacted (internships, course development, scholarships, lab experience, etc.). While less common, some programs focus on community-engaged scholarship and thus the funds may support software, program evaluation, or infrastructure needs of the community partner.

Our findings indicate that there is not one common way to administer a seed fund program. The success of a program will have many variables at specific institutions that can include aligning the project with the mission of the college or university, the needs of the discipline applying for the fund, the scale of the amount awarded, and the metrics put in place to measure success.

\section{UMD Case Study}

Prior to 2010, there was very limited seed funding available in the college of behavioral and social sciences (BSOS) at the University of Maryland. There was campus level funding but for a small unit in the behavioral and social sciences, it was difficult to compete very effectively for sufficient funds that often were directed towards the natural sciences and engineering. To address the lack of research seed funding for the college, the dean negotiated a targeted investment from the campus for college-specific seed funding. The initial year of the program began with a relatively large infusion of funds of about $\$ 600 \mathrm{k}$ and was set to about $\$ 200-250 \mathrm{k}$ in subsequent years.

\section{Program Development}

As shown in the Figure below, the program had a positive impact on research funding in the college in its first two years and it certainly positively impacted morale. However, the program lacked structure and clear strategic direction and the first author of this manuscript was charged by the dean for his incoming role as associate dean for research to revamp the program to strengthen and clarify goals, categories and allocation, selection process, metrics, and reporting and evaluation.

\section{Goals}

The BSOS seed funding program was revamped to start with the strategic planning happening in the College and to focus its goals on supporting that planning. This included strategies to increase overall grant productivity, but it also included a focus on interdisciplinary research, graduate student grant writing, and expanded research opportunities for undergraduate students working in teams with faculty. Finally, it also was viewed as an approach to support individual researchers with a focus on junior investigators as well as more senior investigators with a 
track record of funding who now needed support following a lapse in funding. Along these lines, funding also was used to support a larger program that had lost federal funding and was exploring other larger scale funding options (ADVANCE program funded by NSF).
Funding Categories and Allocation

A wide range of award categories were included with a focus on tying the categories to explicit strategic goals of the College. The following Table outlines these categories.

\begin{tabular}{|c|c|c|}
\hline Category & Goal & Requirements \\
\hline $\begin{array}{l}\text { Collaboratory } \\
\$ 30,000 \text { for each award }\end{array}$ & $\begin{array}{l}\text { To promote high impact } \\
\text { cross-cutting ideas to spark } \\
\text { trans-disciplinary research } \\
\text { in BSOS. Funds support } \\
\text { the formation of interdisci- } \\
\text { plinary research teams } \\
\text { with resources to develop } \\
\text { ideas, conduct research, } \\
\text { and seed larger scale pro- } \\
\text { jects. }\end{array}$ & $\begin{array}{l}\text { Proposals must include } \\
\text { at least two faculty mem- } \\
\text { bers and at least two dif- } \\
\text { ferent departments } \\
\text { within BSOS, additional } \\
\text { collaborators are encour- } \\
\text { aged from across and } \\
\text { outside of campus (na- } \\
\text { tional and international). }\end{array}$ \\
\hline $\begin{array}{l}\text { Level } 1 \text { Seed Projects } \\
\$ 10,000 \text { for each award }\end{array}$ & $\begin{array}{l}\text { Support scholarly research } \\
\text { projects with a well-de- } \\
\text { fined set of aims and meth- } \\
\text { ods, with the specific pur- } \\
\text { pose of "seeding" future } \\
\text { external funding applica- } \\
\text { tions. }\end{array}$ & $\begin{array}{l}\text { Awards can be used to } \\
\text { support a currently un- } \\
\text { funded project or a par- } \\
\text { tially/fully funded pro- } \\
\text { ject that could be ex- } \\
\text { panded significantly } \\
\text { with additional funds. }\end{array}$ \\
\hline $\begin{array}{l}\text { Level } 2 \text { Seed Projects } \\
\$ 20,000 \text { for each award }\end{array}$ & $\begin{array}{l}\text { Support scholarly research } \\
\text { projects with a well-de- } \\
\text { fined set of aims and meth- } \\
\text { ods, with the specific pur- } \\
\text { pose of "seeding" future } \\
\text { external funding applica- } \\
\text { tions. }\end{array}$ & \\
\hline $\begin{array}{l}\text { BSOS ADVANCE Schol- } \\
\text { ars } \\
\$ 10,000 \text { for each award }\end{array}$ & $\begin{array}{l}\text { The BSOS ADVANCE } \\
\text { Scholar Award will sup- } \\
\text { port a junior scientist who } \\
\text { will serve as Principal In- } \\
\text { vestigator and a senior sci- } \\
\text { entist who will serve as Co- } \\
\text { Investigator/Mentor. }\end{array}$ & $\begin{array}{l}\text { Principal Investigator } \\
\text { must be a woman and be } \\
\text { at the rank of Assistant } \\
\text { Professor. The senior sci- } \\
\text { entist also must be a } \\
\text { woman and rank beyond } \\
\text { Assistant Professor. }\end{array}$ \\
\hline
\end{tabular}




\begin{tabular}{|c|c|c|}
\hline Category & Goal & Requirements \\
\hline $\begin{array}{l}\text { Post Start-up Research } \\
\text { Support } \\
\$ 10,000 \text { for each award }\end{array}$ & $\begin{array}{l}\text { To support research activi- } \\
\text { ties after traditional start- } \\
\text { up packages end. Focuses } \\
\text { on a project that can be de- } \\
\text { veloped further into an ex- } \\
\text { ternal funding proposal. }\end{array}$ & $\begin{array}{l}\text { Must be in years } 4-6 \text { of } \\
\text { initial appointment at } \\
\text { UMCP. }\end{array}$ \\
\hline $\begin{array}{l}\text { Master's Thesis / Pre-can- } \\
\text { didacy Research } \\
\$ 1,500 \text { for each award }\end{array}$ & $\begin{array}{l}\text { To support Master's Thesis } \\
\text { or comparable Pre-candi- } \\
\text { dacy Research expendi- } \\
\text { tures (e.g., participant pay- } \\
\text { ment, travel costs, confer- } \\
\text { ence fees). Funds cannot be } \\
\text { used to supplement sti- } \\
\text { pends. }\end{array}$ & $\begin{array}{l}\text { Must be in good stand- } \\
\text { ing in their program, in } \\
\text { their first } 3 \text { years since } \\
\text { entry into the program, } \\
\text { and yet to complete the } \\
\text { thesis project. }\end{array}$ \\
\hline $\begin{array}{l}\text { Doctoral Dissertation Re- } \\
\text { search } \\
\$ 2,500 \text { for each award }\end{array}$ & $\begin{array}{l}\text { Supports support Doctoral } \\
\text { Dissertation research ex- } \\
\text { penditures (e.g., partici- } \\
\text { pant payment, travel costs, } \\
\text { conference fees). Funds } \\
\text { cannot be used to supple- } \\
\text { ment stipends. }\end{array}$ & $\begin{array}{l}\text { Must be in good stand- } \\
\text { ing in their program, } \\
\text { have advanced to candi- } \\
\text { dacy, in their first } 6 \text { years } \\
\text { since entry into the pro- } \\
\text { gram, and yet to com- } \\
\text { plete the dissertation } \\
\text { project. }\end{array}$ \\
\hline $\begin{array}{l}\text { BSOS Summer Scholars } \\
\$ 3,000 \text { for each award }\end{array}$ & $\begin{array}{l}\text { Supports undergraduate } \\
\text { students independent re- } \\
\text { search projects in the sum- } \\
\text { mer. Students may expand } \\
\text { their research into an inde- } \\
\text { pendent study or Honors } \\
\text { thesis during following fall } \\
\text { semester. }\end{array}$ & $\begin{array}{l}\text { BSOS Summer Scholar } \\
\text { proposals are jointly } \\
\text { submitted by the under- } \\
\text { graduate student and the } \\
\text { faculty mentor who pro- } \\
\text { vides a support letter. }\end{array}$ \\
\hline $\begin{array}{l}\text { Mentored Undergraduate } \\
\text { Research Teams } \\
\$ 2,500 \text { for each award }\end{array}$ & $\begin{array}{l}\text { To support creative efforts } \\
\text { to provide outstanding un- } \\
\text { dergraduate research expe- } \\
\text { riences to a small group of } \\
\text { undergraduates. }\end{array}$ & $\begin{array}{l}\text { Students should be BSOS } \\
\text { majors unless the appli- } \\
\text { cation includes a clear } \\
\text { statement arguing for } \\
\text { the value of targeting } \\
\text { students outside of } \\
\text { BSOS. }\end{array}$ \\
\hline
\end{tabular}

\section{Selection Process and Criteria}

To provide as fair and equitable of a selection process, the BSOS brought together one faculty member from each of its 10 departments. The faculty member in a particular department served as the lead reviewer for each grant from their department (unless there was a conflict of 
interest) but all committee members voted on each application (modeled off the NIH grant review approach). Unlike tenure review where departmental colleagues often are recused, there was concern that the level of expertise needed to evaluate the proposals would be insufficient if the departmental representative was recused. It is notable that even with ensuring representation from all 10 departments, it was clear that the level of specificity and disciplinary knowledge needed to evaluate these proposals equitably was challenging. Anecdotally, it appeared that having someone closely tied to your discipline not only didn't provide an advantage, but there appeared to be significantly higher standards in reviews from those individuals.

\section{Metrics}

The metrics on which an application is funded is central to the success of the program. From our survey of other deans, most reported that the quality of the current idea was more important for funding. We aimed to place as much focus on outcomes as the merit of the idea itself. We also were sure to align the metrics with the larger strategic goals of the college. The guidelines for metrics were constructed to emphasize these issues and are reflected below.

In addition to the intellectual merit of the proposal, preference will be given to applications that: a) show previous efforts to obtain external funding; b) provide a detailed plan for meaningful outcomes resulting from the seed award with a timeline of measureable outcomes that include research activities, funding efforts, and scholarly products; c) provide support for students from un- derrepresented groups; and d) propose particularly efficient use of funds and smaller budgets as appropriate.

Asking faculty at the start of the process to focus as much on the products of the funding as the idea itself was challenging for some group members at the start of the process, though there was acknowledgement by the end of the process that this approach was a bit more objective.

\section{Reporting and Evaluation}

Outlining metrics is a crucial step in building a seed program, but these metrics aren't relevant if the proper reporting and evaluation process isn't in place. It was our experience at the start of the BSOS program at UMD that while significant energy would go into choosing the most meritorious applications, little emphasis was provided for reporting from the investigators on outcomes as well as overall program evaluation from the dean's office. Of note, in the initial years of the program, the reporting occurred upon the end of the funding period. In most cases, this wasn't a sufficient time for the likely outcomes to have come to fruition and the reporting indicated most often that progress was ongoing. This made any real evaluation quite limited. Outcomes were tracked over time to establish success but there was no sense of accountability in cases where outcomes weren't achieved.

We instituted several strategies to provide a clearer focus on achieving the stated outcomes, which is particularly relevant to the extent that the emphasis on proposed outcomes in the stated criteria for funding decisions. As noted below, we instituted a progress report 
9 months into the 12-month funding. This allowed for the evaluation of outcomes that were proposed mid project and served as a reminder to recipients of the impending final report. That final report was extended out a full 9 months after the end of the project (at 21 months). This timeline was chosen to provide sufficient time for proposed outcomes to come to fruition (and be reported on) and to coincide with the proposal evaluation for the next year of seed funding. The guidelines for reporting and evaluation were constructed to emphasize these issues and are reflected below.

Acceptance of funds acknowledges your willingness to provide a one-page progress report at 9 months and again at 21 months, and to attend a meeting of seed funding recipients to present progress at these same time points. Please note that research funding must be spent in the first year (carry-over is not permitted) but there is an expectation of continued progress from the project at least through a second year. Progress reports will include the initial proposed timelines and actual progress for research activities, funding efforts, and scholarly products. Where a disparity exists, a plan for addressing this disparity going forward must be proposed.

For the timeline referenced in b) above, greater detail will increase odds of seed funding and should include target funding agencies and deadlines for applications as well as possible publication outlets and submissions timelines for the products. Specific details of actual productivity may vary from what is proposed (submission to Journal X instead of Journal $Y$, or grant submissions in June and October instead of February and June) but the overall scope should be consistent.

\section{Results/lessons learned}

The results of the program as a function of grant dollars awarded for a given year of seed funding are provided in the figure below. As can be seen the return on investment indicated the value of the program in the initial two years, but clearly the increased focus on goals, categories and allocation, selection process, metrics, and reporting and evaluation in the third year had a dramatic impact on return.

It is important to note that return on investment is challenging to interpret with full clarity. Indeed, it is difficult to determine with any certainty that a particular successful grant would not have happened at all or with the level of success if seed funding wasn't available. The results here when considered across years provide are quite meaningful in suggesting the importance of the added focus across years, but the larger point of clearly establishing impact of a seed grant is challenging. It is also notable that return on investment as measured here requires an appreciation for the fact that the investor is largely not the one reaping the financial rewards. It is true that a share of indirect costs is returned to the college which can offset some of the costs, but this investment is best conceptualized with the return considered in terms of research output, staff and students hired and getting significant development experiences, and the overall prestige of the unit. This of course has many benefits, but it is not in the same currency as the investment, which may be more relevant in difficult financial times. 


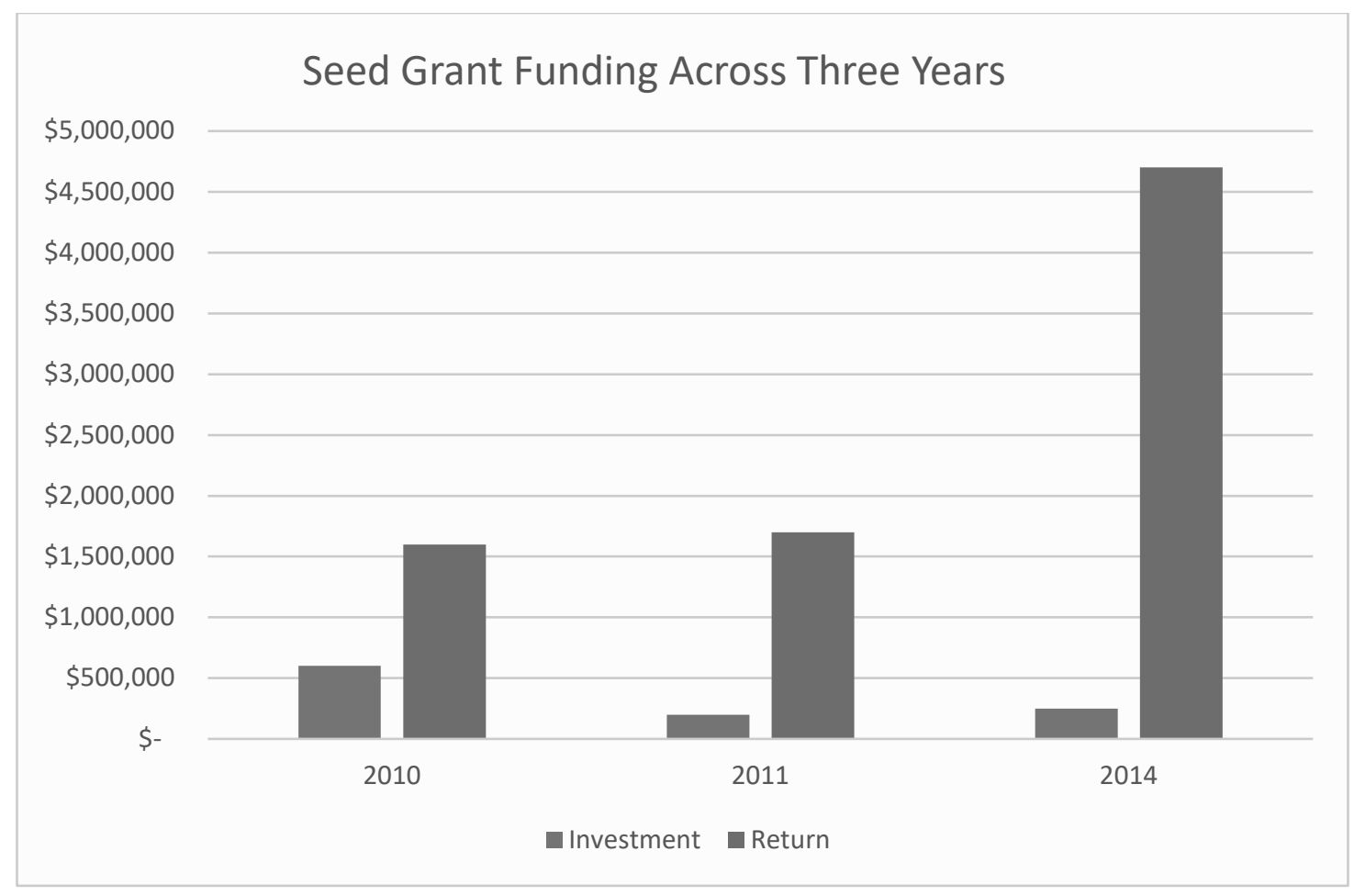

\section{Building a Seed Program from the Ground}

There are many useful lessons that emerge from the survey of deans, the results of the BSOS program, the goal of being strategic with seed funding, and the complexities of addressing the full range and needs of a comprehensive liberal arts and sciences college. In a time of uncertain budgets, efforts to develop seed programs must consider creative strategies raising the necessary funds. Research funding may not always be the first thing on the minds of endowment officers and potential funders, and therefore it is important to be able to tell the story of the full impact of research.

Being able to articulate how research builds the prestige of the institution is important. However, the ability to emphasize how more research funding has an impact on the education mission for students also can be of great importance. For our college this includes a focus on developing student research experiences that result from increased research and funding for that research. Building enthusiasm for these fundraising priorities and for the use of internal funds for seed grants requires a clear message in how these opportunities support the range of the goals of the college.

While there are many standard ways that seed programs have operated in a very successful manner, there are somewhat nontraditional approaches that also could be considered. Most approaches tend to provide one infusion of funds. One alternative approach would be to provide very small funds up front with little review of the original idea but with significant review of progress, with strong progress producing additional 
funding. A second approach would be to hold a portion of funds to support highly meritorious but unfunded applications that have been submitted for external funding. If an application is viewed positively, it is quite likely that additional progress would have a positive impact. This approach can be ideal to stimulate graduate student funding, where low funding rates for external grants can be a clear impediment to students submitting applications for these grants. Likely neither of these approaches alone would make for an ideal strategy for program evaluation, but there could be value in efforts to consider integrating aspects of these approaches into more traditional seed programs.

\section{Conclusion}

Clearly, seed funding is a crucial part of a research-intensive college. At a time where budgets are shrinking, college's may find fewer resources available. For this reason, there must be considerable creativity in how funds are raised and how programs are established to support research productivity along with the strategic goals set. While not without a range of challenges from raising the funds to building the program and selecting awardees, there is no doubt that seed funding can be an essential part of the research mission of a comprehensive liberal arts and sciences college, particularly when developed and conducted in a strategic manner. 